\title{
CILEGON: DARI KOTA ADMINISTRATIF SAMPAI KOTA (1986-2005)
}

\author{
Oleh Herry Wiryono \\ Balai Pelestarian Sejarah dan Nilai Tradisional Bandung \\ Jln. Cinambo No. 136 Ujungberung Bandung \\ Email: bpsntbandung@ymail.com
}

\begin{abstract}
Abstrak
Kota Cilegon yang terletak di ujung barat Pulau Jawa memiliki kawasan pesisir yang sangat berpotensi untuk dikembangkan. Pengembangan investasi yang dinilai layak, antara lain sektor industri, pariwisata, pelabuhan, pergudangan, instalasi, dan kawasan komersial. Dengan segala potensi yang ada diharapkan masyarakat, terutama pihak swasta dan para investor dapat mengambil bagian dalam pembangunan Kota Cilegon ke depan.
\end{abstract}

Kata Kunci: Cilegon, Sejarah Kota.

\begin{abstract}
Cilegon town which located in tip of west Pulau Jawa has a real coastal area area potency to be developed. Expansion of invesment assessed is competent for example industrial sector, tourism, port, warehousing, installation, and commercial area. With all the potencies is expected by public, especially the side of private sector and the investors can take a hand in development of Cilegon town forwards.
\end{abstract}

Keywords: Cilegon, History of City.

\section{A. Pendahuluan}

Cilegon adalah sebuah daerah yang memiliki rentang sejarah yang sangat panjang. Apabila merunut ke belakang dan mencermati lembaran-lembaran sejarah yang ada, daerah Cilegon telah mengalami beberapa kali perubahan pemerintahan sejak statusnya sebagai distrik (kawedaaan pada masa pemerintahan kolonial Belanda), kecamatan, Kota Administratif sampai terbentuk Kota Cilegon pada tahun 1999.

Selama kurun waktu 20 tahun sejak resmi menjadi kota administratif, Cilegon mengalami perkembangan yang cukup pesat baik dalam penyelenggaraan pemerintahan, pembinaan kemasyara- katan, dan pembangunan fisik. Selain itu Cilegon juga berperan sebagai pintu gerbang Jawa-Sumatera dan perkembangannya Industri Strategis Nasional. Semakin pesatnya perkembangan Kota Administratif Cilegon, semakin besar pula tuntutan masyarakat yang mendesak agar Kota Administratif Cilegon ditingkatkan menjadi kotamadya, dengan harapan pelayanan terhadap masyarakat menjadi maksimum. Dengan memperhatikan perkembangan tersebut, pemerintah mengeluarkan Undang-undang No. 15 tahun 1999 tentang Pembentukan Kotamadya Daerah Tingkat II Depok dan Kotamadya DT II Cilegon. Terwujudnya status Kota 
Administratif Cilegon menjadi Kotamadya Daerah Tingkat II Cilegon baru dilaksanakan pada tanggal 27 April 1999. Bersamaan dengan itu, dilakukan pula pelantikan Drs. H. Tb. Rifa'i Halir sebagai pejabat Walikotamadya Daerah Tingkat II Cilegon.

Dengan perubahan status Cilegon dari kotif menjadi kota, maka terjadi perubahan struktur organisasi pemerintahan dan kewenangan. Penyesuaian struktur organisasi pemerintahan dan kewenangan pemerintah Kota Cilegon dilakukan hingga dikeluarkannya Perda No. 46 tahun 2000 tanggal 11 Januari 2001 mengenai Kewenangan yang berlaku mulai tanggal 12 Januari 2001, serta Perda No. 47 tahun 2000 tentang Pembentukan Perangkat Daerah dan Perda No. 48 tahun 2000 tentang Susunan Organisasi Perangkat Daerah yang juga berlaku mulai 12 Januari 2001 dan dinyatakan berlaku efektif mulai bulan Mei 2001.

Dengan melihat perubahanperubahan yang terjadi di dalam masyarakat Kota Cilegon, dirasa perlu melakukan kajian terhadap perubahanperubahan tersebut dari segi historis. Oleh karena itu, dilakukan penelitian mengenai Sejarah Kota Cilegon yang difokuskan pada studi perkembangan pemerintahan yang pernah ada dan terjadi di Kota Cilegon.

\section{B. Hasil dan Bahasan}

\section{Kota Administratif Cilegon}

Landasan pengembangan perkotaan diharapkan dapat memberikan gambaran fungsi, peranan, dan kedudukan kota dalam lingkup nasional dan regional yang menggambarkan manifestasi usaha manusia dalam mencapai tingkat kehidupan lebih baik dan lebih banyak. Kota Cilegon yang terletak di ujung barat Pulau Jawa merupakan bekas Kawe- danaan (Wilayah Kerja Bupati Wilayah Cilegon), yang meliputi 3 (tiga) kecamatan yaitu Kecamatan Cilegon, Bojonegoro, dan Pulo Merak.

Hadirnya pabrik Trikora tahun 1960 yang berubah menjadi PT Krakatau Steel telah mendorong pembangunan dan perkembangan yang sangat pesat bagi wilayah ini, yang akhirnya mempengaruhi kondisi sosial budaya dan tata guna lahan. Daerah persawahan dan perladangan menjadi daerah industri, perdagangan, jasa, dan perumahan serta pariwasata.

Keadaan tersebut menggambarkan bahwa Kota Cilegon adalah kota kecil yang memiliki fasilitas kota besar, dan pada kenyataannya sedang berkembang sesuai dengan perkembangan pembangunan.

Berdasarkan pasal 72 ayat (4) Undang-undang Nomor 5 Tahun 1974 tentang Pokok-Pokok Pemerintah di Daerah; atas usul Pemerintah Daerah Tingkat II Serang No. 86/Sek/Bapp/VII/ 84 tentang usulan pembentukan Kota Administratif Cilegon; dan atas pertimbangan yang objektif, maka dikeluarkan Peraturan Pemerintah No. 40 Tahun 1986 tanggal 17 September 1986 tentang pembentukan Kota Administratif Cilegon. Selain itu ditetapkan pula luas Kota Administratif Cilegon yaitu 17.550 ha yang meliputi 3 (tiga) wilayah kecamatan, yaitu Kecamatan Pulo Merak, Cilegon, dan Ciwandan; serta 1 (satu) Perwakilan Kecamatan Cilegon di Cibeber. Adapun Kecamatan Bojonegoro masuk wilayah kerja pembantu Bupati Wilayah Kramatwatu.

Berdasarkan PP No. 3 tahun 1992 tanggal 7 Februari 1992 tentang penetapan Perwakilan Kecamatan Cibeber menjadi Kecamatan Cibeber, maka sejak saat itu Kota Administrasi Cilegon memiliki 4 kecamatan, yaitu Kecamatan Pulo Merak, Ciwanden, Cilegon, dan Cibeber. 
Tujuan pembentukan Kota Administratif Cilegon ini adalah dalam rangka meningkatkan kegiatan pe-nyelenggaraan pemerintahan secara berdaya guna dan berhasil guna, serta merupakan sarana bagi pembinaan wilayah dan unsur pendorong yang kuat bagi usaha peningkatan laju pembangunan.

Berdasarkan Peraturan Pemerintah Pasal 3 No. 40 tahun 1986, bahwa Kota Administratif Cilegon dan juga Kota Administratif lain yang berada di daerah Kabupaten berada di bawah dan bertanggungjawab kepada pemerintah Kabupaten induk masing-masing.

Cilegon telah berstatus Kota Administratif selama 11 tahun. Selama itu, perkembangan dalam penyelenggaraan pemerintahan, pembinaan kemasyarakatan, dan pembangunan fisik cukup pesat. Dalam perjalanannya, Kota Administratif Cilegon dipimpin oleh beberapa orang yang menjabat sebagai Walikota, antara lain:

1. Drs. Nurman Suriadinata(1987-1988)

2. H. Nano Abdullah Dudaya, BA (1988-1989)

3. Drs. H. Nurdi Achmadi (1989-1992)

4. Drs. H. Aan Hermana ASW (PYMT Walikota)

(Mei 1992-Oktober 1992)

5. Drs. H. Ma'mun Suchari (1992-1997)

6. Ir. H. Setia Hidayat (PLH Walikota) (Juli 1997-Juni 1998)

7. Drs. H. Tb. Rifa'i Halir (1998-1999)

\section{Kota Cilegon Saat Ini}

\section{a). Kondisi Umum Kota Cilegon}

Dalam UU No. 5/1974 tentang

Pokok-pokok Pemerintahan di Daerah, dijelaskan bahwa pembentukan daerah harus ditetapkan oleh Undang-undang Dasar. Hukum pembentukan Kotamadya DT II Cilegon adalah Undang-undang No. 15 tahun 1999 tentang Pembentukan Kotamadya. Kotamadya DT II Cilegon disahkan pada tanggal 20 April 1999, dengan Drs. H. Tb. Rifa'I Halir diangkat sebagai pejabat Walikota Cilegon sambil menunggu Walikota Cilegon yang akan dipilih oleh DPRD yang dibentuk berdasarkan hasil pemilu mendatang.

Berdasarkan letak geografisnya, Kota Cilegon berada di bagian ujung sebelah barat Pulau Jawa dan terletak pada posisi; $5^{\circ} 52^{\prime} 24^{\prime \prime}-6^{\circ} 04^{\prime}$ 07" Lintang Selatan (LS) dan $105^{\circ} 54^{\prime} 05^{\prime \prime}$ $106^{\circ} 05^{\prime} 11^{\prime \prime}$ Bujur Timur (BT). Secara administratif wilayah Kotamadya Cilegon mempunyai batas-batas wilayah sebagai berikut:

1. Sebelah utara berbatasan dengan Kecamatan Bojonegoro (Kabupaten Serang);

2. Sebelah barat berbatasan dengan Selat Sunda;

3. Sebelah selatan berbatasan dengan Kecamatan Mancak dan Kecamatan Anyer (Kabupaten Serang);

4. Sebelah timur berbatasan dengan Kecamatan Kramatwatu (Kabupaten Serang).

Berdasarkan Perda Nomor 15 tahun 2002 dibentuk kembali 4 kecamatan baru, sehingga kini Kota Cilegon memiliki 8 (delapan) kecamatan; serta Kota Cilegon memiliki 2 (dua) kelurahan dan 41 desa.

\section{b). Pembangunan Kota Cilegon 1). Bidang Pemerintahan}

Pembangunan Kota Cilegon telah memasuki tahun ketujuh sejak awal terbentuknya Kota Cilegon berdasarkan UU Nomor 15 tahun 1999. Beberapa hasil pembangunan telah dapat dirasakan oleh segenap masyarakat pada berbagai bidang pembangunan, baik pendidikan, kesehatan, sosial perekonomian, maupun pendidikan.

Berdasarkan kondisi, potensi, permasalahan, dan tantangan yang masih harus dihadapi Kota Cilegon, serta sebagai komitmen dalam menjaga ke- 
sinambungan penyelenggaraan pemerintahan. Pemerintah Kota Cilegon diharapkan mampu untuk mendorong proses transformasi pemerintahan yang efisien, akuntabel, responsif dan aspiratif.

Dalam penyelenggaraan pemerintah daerah, pemerintah Kota Cilegon berupaya untuk menciptakan kelembagaan yang berorientasi pada pelayanan publik, dengan memperhatikan dimensi jumlah penduduk, sumber daya aparatur pemerintah, potensi dan kemampuan keuangan daerah, serta kemampuan untuk menggerakkan investasi melalui kerjasama kemitraan antara pemerintah, masyarakat, dan swasta.

\section{2) Politik}

Berdasarkan pemilu tahun 1999 , dihasilkan susunan anggota DPRD Kota Administratif Cilegon dengan kursi terbanyak diduduki Golkar sebanyak 14, PDIP sebanyak 12 kursi, kemudian diikuti oleh PPP dan PAN masingmasing 7 kursi.

Memasuki tahun 2004, pemerintah Kota Cilegon kembali melakukan pesta demokrasi melalui pemilihan anggota legislatif yang baru. Saat itu di Kota Cilegon pemilihan anggota legislatif diikuti oleh 24 partai politik.

Berdasarkan pemungutan suara hasil sidang angota DPRD, maka yang terpilih sebagai Ketua DPRD Kota Cilegon adalah K.H. Fathullah Syam'un, L.M.L., dengan dibantu oleh dua orang wakil ketua yaitu Drs. H. Bahri Syamsu Arief dan Drs. Dimyati Suja'i.

Berdasarkan Keputusan Mendagri, masa jabatan walikota Cilegon berakhir pada tahun 2005. Oleh karena itu pada tahun tersebut diadakan pemilihan Walikota Cilegon yang baru. Pemilihan dilakukan secara langsung oleh masyarakat Cilegon. Hal ini merupakan bagian dari proses demokratisasi yang sedang bergulir, khususnya di Kota Cilegon maupun di tanah air saat ini.

Calon yang mengikuti pemilihan calon dan wakil Kepala Daerah Kota Cilegon ada tiga orang, yaitu $\mathrm{H}$. Ade Miftah,SE yang berpasangan dengan Ni'matullah Mansur, H. Tb. Aat Syafaat, S.sos, M.Si dengan Drs. Rusli Ridwan, M.Si, dan H. Entol Mochamad Sedeli Ali SH dengan Drs. Ir. Tarbin Usman, MM. Pada tanggal 10 Juni 2005, berdasarkan perolehan suara KPUD Kota Cilegon menetapkan H. Tb. Aat Syafaat, S.sos, M.Si dan Drs. Rusli Ridwan, M.Si, sebagai calon Walikota dan Wakil Walikota Cilegon periode 2005-2010.

\section{3) Bidang Perekonomian}

Keberhasilan pembangunan di bidang perekonomian dicerminkan dari perkembangan indikator PDRB, yang mengindikasikan perbaikan, penguatan, dan kemapanan daerah dalam penguatan struktur perekonomian daerah. Laju Pertumbuhan Ekonomi (LPE) Kota Cilegon meningkat dari sekitar $6,0 \%$ pada tahun 2000 menjadi $7,3 \%$ pada tahun 2006. Adapun nilai PDRB juga seiring dengan peningkatan LPE. Nilai PDRB atas dasar Harga Berlaku meningkat dari sekitar Rp. 6,64 Trilyun pada tahun 2000 meningkat menjadi Rp. 13,13 Trilyun pada tahun 2006. Demikian pula PDRB atas dasar Harga Konstan, pada tahun 2000 nilainya sebesar Rp. 2,65 Trilyun meningkat menjadi Rp. 3,8 Trilyun pada tahun 2006.

Laju PDRB secara signifikan bisa terlihat dalam perkembangan dari tahun ke tahun, dimana industri pengolahan selalu menjadi unggulan, disusul dengan pertambangan dan penggalian, per-dagangan, hotel dan restoran; baru sektor lainnya, antara lain pertanian, peternakan, hutan, perikanan, listrik, gas, dan air bersih. 
Pembangunan sektor ekonomi di Kota Cilegon mengalami kemajuan yang signifikan. Hal ini dapat dilihat dari perkembangan pendapatan Asli Daerah (PAD) Kota Cilegon yang mengalami peningkatan dari tahun ke tahun. Pada tahun 2000 realisasi PAD Kota Cilegon sebesar Rp. 17.536.001.510 dan pada tahun 2001 meningkat menjadi Rp. 39.733.003.162,-, pada tahun 2002 meningkat menjadi Rp. 63.549.937.903,-. Pendapatan Asli Daerah Kota Cilegon pada tahun 2003 meningkat menjadi Rp. 72.333.548.635,-, realisasi terus mengalami peningkatan sehingga mencapai Rp. 87.438.712.980,- pada tahun 2004 dan terus meningkat menjadi Rp. 89.849.452.170 pada tahun 2005 .

\section{4) Pendidikan}

Pada awal pemerintahan, kondisi sarana pendidikan dasar sebanyak 161 SD dan 8 MI. Jumlah ruang kelas yang dimiliki sebesar 1.131, dimana kondisi ruang kelas yang baik hanya 293 ruang atau $25,91 \%$ dan kondisi rusak 838 ruang atau $74,09 \%$. Dalam perkembangan sampai tahun 2005, jumlah sekolah menjadi 166 SD Negeri/Swasta dan 11 MI/MIS dengan jumlah ruang kelas keseluruhan sebanyak 1.229 ruang dan dalam kondisi baik.

Saat itu sarana pendidikan berjumlah 53 SMP/MTS dan 28 SMAN/MA/SMK, meliputi 218 ruang kelas SMP/Mts dan 112 ruang kelas SMA/MA/SMK, dengan kondisi baik SMP/MTs sebanyak 87 ruang kelas (sekitar 40\%), SMA/MA/SMK sebanyak 45 ruang kelas (40\%). Adapun ruang kelas dalam kondisi rusak, SMP/MTs sebanyak 131 (60\%) dan SMA/MA/SMK sebanyak 67 (60\%).

Pembangunan ruang kelas baru serta pembangunan unit sekolah baru, pelaksanaan fisik bangunannya menggunakan 2 (dua) pola kegiatan, yaitu pola revitalisasi dan pola imbal swadaya, sehingga pada akhir tahun 2005, kondisi sarana dan prasarana pendidikan menengah Kota Cilegon mengalami penambahan ruang kelas dan unit sekolah baru sebanyak 326 SMP/MTs dan 141 ruang kelas SMA/MA/SMK.

\section{5) Kesehatan}

Pembangunan bidang kesehatan ditunjukkan dengan semakin meningkatnya tingkat kesehatan masyarakat, yang diindikasikan meningkatnya Angka Harapan Hidup (AHH) dari 63,76 tahun (tahun 2000) menjadi 72,33 tahun (tahun 2005), Kondisi tersebut mencerminkan peningkatan peluang hidup penduduk Kota Cilegon bertambah. Indikasi lainnya yang menunjukkan peningkatan kesehatan masyarakat ditunjukkan dengan keberhasilan upaya persuasif melalui peningkatan fungsi Posyandu, Puskesmas, UPTD Paru hingga RSUD dalam meningkatkan pelayanan kesehatan masyarakat.

Fasilitas kesehatan di Kota Cilegon sudah tersebar sampai ke tingkat paling bawah, sehingga semua masyarakat dapat mengakses dengan mudah fasilitas tersebut. Terutama dengan adanya Askeskin, yang bertujuan untuk menjamin pemeliharaan kesehatan setiap penduduk serta pelayanan kesehatan yang dapat dijangkau oleh seluruh lapisan masyarakat.

Perilaku hidup bersih dan sehat merupakan kunci dari paradigma sehat. Apabila masyarakat telah memiliki perilaku sehat maka permasalahan kesehatan secara individu akan teratasi. Pemerintah Kota Cilegon setiap tahunnya, dalam hal ini Dinas Kesehatan telah melaksanakan penyuluhan dan pembinaan tentang kesehatan, baik kepada pelajar maupun masyarakat secara umum. 


\section{6) Agama}

Agama yang paling banyak dianut oleh masyarakat Cilegon adalah Islam 92.64\%, Katolik 2.36\%, Protestan 3.84\%, Budha $0.4 \%$, dan lainnya $0.03 \%$. Hingga akhir tahun 2001, jumlah tempat ibadah di Kota Cilegon tercatat 530 masjid, 16 langgar, 3.026 musholla, 104 gereja, dan 3 vihara/pura. Tempat ibadah sebanyak itu mengalami peningkatan dibandingkan tahun 1998 yang hanya 168 masjid, 349 langgar dan musholla, 27 gereja dan 4 vihara/pura (BPS, 2002: xi).

\section{7) Infrastruktur}

Infrastruktur merupakan salah satu permasalahan pokok dalam pembangunan perkotaan, karena karateristiknya yang menyedot dana yang besar, tetapi dapat menghasilkan peluang bagi tumbuhnya berbagai macam kegiatan ekonomi di dalam kota. Keberadaan Cilegon Infratruktur Project diharapkan dapat memberikan kontribusi yang besar terhadap pembangunan Kota Cilegon pada umumnya.

Saat ini, pemerintah Kota Cilegon merasa perlu untuk mengembangkan sektor-sektor ekonomi perkotaan lainnya, untuk mengimbangi dominasi dari sektor industri. Apalagi saat ini, fungsi dan peran Kota Cilegon sebagai kota perdagangan bagi daerah sekitarnya, seperti Serang dan Bojonegoro sudah semakin termanifestasikan dalam pola pemanfaatan ruang Kawasan Pusat Kota Cilegon yang selalu ramai. Oleh karena itu, perlu adanya upaya dari Pemerintah Kota untuk merangsang pertumbuhan ekonomi tersebut dengan membangun beberapa infrastruktur sebagai pemicu perkembangan kota.

Dalam rangka menindaklanjuti dasar pembangunan Cilegon Infratruktur Project, maka pembangunan proyekproyek infrastruktur di dalam Kota Cilegon ditekankan pada proyek-proyek yang termasuk bagian dalam Rencana Strategis Kota Cilegon Tahun 2001-2005. Proyek pembangunan infrastruktur yang termasuk dalam prioritas Rencana Jangka Menengah ke-2 meliputi:

1). Pembangunan Jalan Lingkar Selatan;

2). Pembangunan terminal terpadu;

3). Pembangunan Pasar Kota; dan

4). Penataan Kawasan Kubangsari.

\section{Pembangunan Kota Cilegon Jangka Panjang \\ a) Arah Kebijakan Pembangunan Kota Cilegon \\ Dalam rangka pembangunan} jangka panjang, perlu diletakkan kesepahaman bersama mengenai kondisi Kota Cilegon yang diharapkan di masa depan. Kondisi masa depan Kota Cilegon diharapkan sejalan dengan Visi Pembangunan Jangka Panjang Daerah Provinsi Banten tahun 2002-2022, yaitu "Dengan Iman dan Taqwa Menjadi Provinsi Terkemuka di Bidang Agrobisnis, Kemaritiman, Pariwisata, Perdagangan, dan Industri Berwawasan Lingkungan dengan Berbasis Sumberdaya Manusia yang Handal dan Agamis Menuju Banten Maju dan Sejahtera".

Modal dasar pembangunan Kota Cilegon lainnya ditunjukan oleh posisi geostrategis dalam konstelasi pembangunan lingkup regional, nasional, maupun internasional, sebagai berikut:

1). Kota Cilegon sebagai salah satu pusat pertumbuhan wilayah Provinsi Banten;

2). Kota Cilegon sebagai simpul sistem transportasi Jawa-Sumatera;

3). Kota Cilegon sebagai Pusat Kegiatan Wilayah (PKW) secara nasional;

4) Kota Cilegon sebagai potensi inletoutlet terhadap lokasi pasar dunia;

5) Kota Cilegon sebagai Pusat Kegiatan Wilayah (PKW) secara nasional.

Dengan mempertimbangan sinergitas terhadap harapan pencapaian pem- 
bangunan nasional dan Provinsi Banten di atas, serta dengan memperhatikan modal dasar pembangunan yang dimiliki, kondisi pembangunan hingga saat ini, tantangan pembangunan yang dihadapi dalam 20 tahun mendatang, dan faktor strategis juga potensi yang dimiliki oleh masyarakat, pemangku kepentingan, serta pemerintah Kota Cilegon, maka dibuatlah Filosofi Kota Cilegon masa depan, yaitu: "CILEGON PUSAT INDUSTRI DAN JASA TERDEPAN DI PULAU JAWA".

Sebagai pusat industri dan jasa terdepan di Pulau Jawa, industri di Kota Cilegon diharapkan memiliki kemampuan untuk memanfaatkan keunggulan dibandingkan pusat industri lainnya di Pulau Jawa. Khususnya atas posisi strategis Kota Cilegon sebagai simpul transportasi regional, nasional, dan internasional, yang didukung dengan keberadaan dan kinerja pelabuhan yang ada.

Berkaitan dengan kondisi Kota Cilegon yang diharapkan di masa depan, maka dalam rangka mewujudkan filosofi pembangunan sebagai Pusat Industri dan Jasa Terdepan di Pulau Jawa, diperlukan serangkaian Arahan Umum Pembangunan sebagai payung utama rumusan Langkah Taktis Strategis yang akan ditempuh dalam tahapan pembangunannya.

Keberadaan industri di Kota Cilegon selain memberikan dampak positif, pada sisi lain juga memunculkan permasalahan yang cukup komplek, di antaranya yang pokok yaitu masalah pencemaran lingkungan, kesenjangan antara pelaku industri besar/menengah dengan industri kecil/rumah tangga, ketenagakerjaan, serta masalah keamanan.

Penanganan berbagai masalah tersebut tentunya tidak dapat dilaksanakan oleh pemerintah daerah, melainkan dengan melibatkan segenap tokoh daerah, khususnya para pelaku industri. Dengan demikian, solusi yang dihasilkan dapat memuaskan semua pihak yang berkepentingan.

Hingga saat ini, partisipasi aktif dalam pembangunan daerah dari pelaku industri di Kota Cilegon, baik yang berada di kawasan industri maupun non kawasan telah menunjukkan hasil yang cukup menggembirakan, dan diharapkan dapat terus dikembangkan lebih jauh agar Kota Cilegon memiliki daya saing dalam era globalisasi dan perdagangan bebas yang sudah berada di depan mata.

\section{b) Strategi Pencapaian Cilegon sebagai Pusat Industri dan Jasa di Pulau Jawa}

Letak geografis Kota Cilegon serta keberadaan berbagai industri besar di wilayah ini, merupakan salah satu kekuatan besar untuk menjadikan Kota Cilegon sebagai pusat industri dan jasa di Pulau Jawa. Sebagai pusat industri dan jasa tentunya berfungsi juga sebagai pusat pertumbuhan ekonomi serta pusat pergerakan distribusi barang dan jasa.

Namun demikian, keunggulan komparatif tersebut juga membawa sejumlah masalah dalam jangka panjang, seperti halnya perubahan geomorfologi dan lingkungan hidup. Penurunan kualitas lingkungan hidup karena faktor manusia jika tidak diantipasi akan terus meningkat. Ketersediaan sumber daya alam juga semakin menurun akibat eksploitasi dan eksplotasi.

Untuk dapat mewujudkan Cilegon sebagai pusat industri dan jasa terdepan di Pulau Jawa, tentunya diperlukan serangkaian strategi sebagai suatu landasan tindak lanjut untuk merespon isu strategi serta prospek pembangunan Kota Cilegon jangka panjang.

Selain strategi jangka panjang, Kota Cilegon membutuhkan strategistrategi khusus, seperti halnya strategi untuk memasarkan daerah. Memasarkan daerah analog dengan mendesain serta merancang produk dan jasa yang mampu 
memenuhi juga memuaskan keinginan serta ekspektasi pasar sasarannya.

Pasar sasaran versi di atas adalah:

- Masyarakat daerah yang membutuhkan jasa layanan publik yang memakai.

- Traders, tourist, dan investor.

- Talenst, developpers, dan organizer.

Dari ketiga pasar sasaran ini dalam memasarkan daerah, secara garis besar mempunyai tiga langkah strategis yaitu:

- Menjadi tuan rumah yang baik.

- Memperlakukan pasar sasaran sebagaimana mestinya.

- Menjadikan Cilegon sebagai rumah bagi ribuan perusahaan atau turis.

\section{c) Tantangan Pembangunan Kota Cilegon 20 Tahun ke Depan}

Pembangunan Kota Cilegon dalam

20 tahun mendatang dihadapkan pada berbagai tantangan yang menyangkut terjadinya perubahan-perubahan yang semakin baik pada seluruh aspek pembangunan. Dalam rangka menggiring perubahan-perubahan sebagaimana diharapkan tersebut, maka perlu dibangun kerangka pencapaian pembangunan.

\section{1) Sosial Budaya}

Dalam kurun 20 tahun ke depan, Kota Cilegon akan mengalami tekanan jumlah penduduk yang semakin besar. Jumlah penduduk yang pada tahun 2005 sebesar 343.476 orang diperkirakan terus meningkat mencapai sekitar 471.390520.863 jiwa hinga tahun 2025, dengan asumsi semakin baiknya berbagai parameter kependudukan seperti menurunnya angka kelahiran, meningkatnya usia harapan hidup, dan menurunnya angka kematian bayi.

Pencapaian indeks pembangunan manusia di Kota Cilegon juga diperkirakan akan semakin meningkat menjadi 84,42-85,59 hinga tahun 2025, terutama dengan adanya upaya pelayanan pendidikan yang berkualitas, yang berorientasi pada peningkatan proporsi penduduk yang menyelesaikan pendidikan dasar ke jenjang-jenjang pendidikan yang lebih tinggi, serta peningkatan daya saing dan relevansi pendidikan terhadap kebutuhan pembangunan.

Sementara itu, kemiskinan di Kota Cilegon masih akan menjadi ancaman yang perlu ditangani secara cermat dan serius. Meskipun proporsi rumah tangga miskin sudah dapat dikurangi tahun 2005 menjadi $17,71 \%$. Keberlanjutan terhadap upaya penanggulangan kemiskinan di Kota Cilegon pada tahun 2025 diharapkan mampu menekan kembali proporsi rumah tangga miskin hingga menjadi 6,18-10,97\%.

\section{2) Perekonomian}

Secara bertahap perekonomian Kota Cilegon diharapkan terus meningkat di masa mendatang, dengan pencapaian sekitar Rp. 46,83-52,29 trilyun. Sejalan dengan kondisi tersebut diharapkan laju pertumbuhan ekonomi Kota Cilegon hingga tahun 2025 menjadi 5,51-5,84\%.

Pencapaian tersebut dimungkinkan bila didukung dengan peningkatan pembentukan modal tetap bruto yang berasal dari swasta (PMA dan PMDN), rumah tangga, dan pemerintah menjadi Rp. 7,93-9,57 trilyun. Pengkondisian pembangunan ekonomi Kota Cilegon tersebut dalam proses pencapaiannya diharapkan disertai dengan kondisi stabilitas ekonomi, kondisi keamanan yang semakin kondusif.

Sejalan dengan harapan terhadap peran sektor ekonomi, maka penciptaan lapangan pekerjaan dalam mengantisipasi pertumbuhan angkatan kerja yang akan semakin meningkat, terutama akan bertumpu pada peran sektor industri. Melalui peran sektor industri ini diharapkan penyerapan tenaga kerja mampu ditingkatkan menjadi 58,51-58,55. 


\section{3) Sarana dan Prasarana}

Tingkat urbanisasi sebagai akibat kesenjangan pola ekonomi perkotaan dan pedesaan cenderung meningkat. Hal ini menimbulkan permasalahan yang terkait dengan pemanfaatan fasilitas publik yang disediakan pemerintah Kota Cilegon oleh penduduk luar Kota Cilegon.

Banyaknya kebutuhan akan tempat tinggal dalam jangka panjang menimbulkan dampak terjadinya pemukiman yang padat. Jika hal ini tidak ditata dengan baik, maka mengakibatkan pemukiman kumuh. Untuk itu, pembangunan perumahan di daerah perkotaan akan mengarah pada model bangunan vertikal karena keterbatasan lahan.

Sebagai implikasi atas perkembangan permukiman di masa mendatang maka semakin banyaknya tuntutan terhadap layanan prasarana dan sarana yang semakin berkualitas, seperti air bersih, energi, serta fasilitas sosial dan umum. Selanjutnya, Kebutuhan terhadap instalasi pengelolaan sampah dan limbah yang modern dan efisien menjadi sangat vital. Misalnya pengadaan sistem jaringan riool kota yang terpusat ke Instalasi Pengelolaan Air Limbah (IPAL).

\section{4) Sumberdaya Alam dan Lingkungan Hidup.}

Secara umum Kota Cilegon akan mengalami perubahan geomorfologi dan lingkungan hidup. Penurunan kualitas lingkungan hidup karena faktor manusia jika tidak diantisipasi akan terus meningkat. Ketersediaan sumber daya alam juga semakin menurun akibat eksploitasi dan eksplorasi. Pencemaran air, udara, dan tanah di Kota Cilegon berpotensi meningkat seiring dengan kemajuan pembangunan dan perubahan pola hidup masyarakat. Selain pencemaran, Kota Cilegon menghadapi ancaman krisis energi dan krisis air bersih karena sebagian besar wilayahnya berbatasan dengan pesisir.

Tersedianya taman kota dan ruang publik sebagai tempat aktivitas bermain dan rekreasi yang rapi, indah, dan terpelihara, sehingga mampu menciptakan kawasan yang semakin sejuk dan asri bagi warga Kota Cilegon.

Dalam kurun waktu 20 tahun ke depan akan terjadi pergeseran tata ruang kota yang berpengaruh pada ekosistem dan kehidupan organisme. Akibat semakin menyempitnya ruang kota, maka beberapa habitat binatang akan terganggu. Keanekaragaman hayati akan menurun jumlahnya karena beberapa spesies hewan dan tumbuhan tidak dapat bertahan lagi.

Bencana alam masih merupakan ancaman bagi Kota Cilegon dalam masa mendatang, di antaranya ancaman yang bersumber dari aktifitas Gunung Krakatau, maupun potensi terhadap dampak aktifitas gempa dan tsunami yang terjadi di daerah selatan Pulau Jawa, dimana salah satu hal yang perlu diperhatikan adalah dampak yang lebih luas atas bencana tersebut terkait dengan keberadaan industri-industri kimia pada kawasan pesisir. Sehingga tantangan di masa mendatang adalah dengan meningkatkan kemampuan pengelolaan lingkungan dalam pencegahan dan penanggulangan bencana alam.

\section{5). Pemerintahan, Politik, dan Keter- tiban Umum}

Dengan semakin meningkatnya kesadaran dan peran masyarakat dalam pembangunan, maka kebijakan pemerintah dituntut untuk lebih transparan dan akuntabel dalam mengikuti perkembangan zaman. Kondisi tersebut harus disertai dengan penataan ke-lembagaan pemerintah Kota Cilegon yang belum dapat secara optimal menjalankan kewenangan, urusan, dan fungsi yang dia- 
manatkan peraturan perundang-undangan, serta mewujudkan profesionalisme, kualifikasi, dan kompetensi SDM aparatur birokrasi pemerintah Kota Cilegon.

Pengelolaan keuangan daerah masa mendatang akan dihadapkan pada tuntutan terhadap peningkatan pendapatan daerah seiring dengan peningkatan pembiayaan pembangunan. Untuk itu, tantangan ke depan yang dihadapi adalah pemanfaatan dana-dana masyarakat dan membuka peluang kerjasama dengan badan usaha dalam penyelenggaraan pembangunan. Sejalan dengan peningkatan pendapatan daerah, tantangan lain yang dihadapi adalah alokasi belanja pembangunan yang semakin berbasis pelayanan publik.

Penguasaan teknologi informasi dan komunikasi akan menjadikan Kota Cilegon lebih cepat tumbuh dan berkembang. Dukungan teknologi informasi dan komunikasi sudah terlihat nyata dalam praktek pembangunan di berbagai kota.

Dalam hal bidang usaha unggulan di Kota Cilegon ke depan, menunjukkan industri masih menjadi pilihan bagi para pengusaha sebagai bidang usaha yang harus dikedepankan. Pandangan tersebut diperkirakan dipengaruhi oleh citra Kota Cilegon saat ini dalam pandangan para pengusaha, yaitu sebagai kota industri. Sementara itu, penguatan peran bidang usaha lainnya di Kota Cilegon ditekankan pada perdagangan dan jasa, pariwisata, serta usaha kecil dan menengah. Adapun pada bidang usaha penunjang perekonomian diarahkan pada perhubungan, perikanan laut, pertanian,dan pertambangan.

Dalam hal pelayanan sekolah dan Rumah Sakit/Puskemas yang berkualitas di Kota Cilegon menjadi perhatian utama yang diharapkan terwujud dalam waktu dekat. Perhatian selanjutnya tertumpu pada terwujudnya layanan prasarana da- sar perkotaan yang berkualitas, meliputi jaringan jalan, listrik, per-sampahan, dan drainase. Selain itu, harapan terhadap terwujudnya sistem transportasi yang baik turut menjadi perhatian pokok, sebagaimana tingkat layanan angkutan perkotaan serta pelayanan terminal/stasiun/pelabuhan.

\section{Penutup}

Cilegon telah berstatus Kota Administratif selama 11 tahun. Selama itu, perkembangan dalam penyelenggaraan pemerintahan, pembinaan kemasyarakatan, dan pembangunan fisik cukup pesat. Dalam perjalanannya Kota Administratif Cilegon dipimpin oleh beberapa orang yang menjabat sebagai Walikota.

Dalam perkembangannya, Kota Administratif Cilegon telah memperlihatkan kemajuan di berbagai bidang baik fisik, sosial dan ekonomi yang cukup pesat. Perkembangan ini tidak lepas dari struktur kota yaitu sebagai pintu gerbang Jawa-Sumatera dan perkembangan Industri Strategis Nasional di Wilayah Cilegon yang diikuti perkembangan pusat perdagangan jasa, industri, pariwisata, dan pemukiman.

Dalam rangka peningkatan status kota administrasi menjadi kotamadya pada tanggal 17 Pebruari 1993 terbit Surat Gubernur Kepala Daerah TK I Jawa Barat No. 650/555-pemda/1993 tentang Persiapan Peningkatan Status Kota Administratif Cilegon, Bekasi, Depok, dan Tasikmalaya menjadi Kotamadya DT II.

Dengan ditetapkannya dan disahkannya Undang-undang No 15 tahun 1999 tanggal 21 April 1999 tentang Pembentukan Kotamadya Daerah Tingkat II Cilegon, dan dengan dilantiknya Drs. H. Tb. Rifa'i Halir sebagai Pejabat Wakotamadya Derah Tingkat II Cilegon pada tanggal 27 April 1999, maka terwujudlah Kota Administratif Cilegon 
menjadi Kotamadya Daerah Tingkat II Cilegon.

\section{DAFTAR PUSTAKA}

Bapeda. 2007.

Buku Saku Kota Cilegon, Tahun 2007.

Bupati Kota Cilegon. 2000.

Laporan Kompilasi Data.

Hendrayati, Fetin et.al. 2005. Inventarisasi dan Dokumentasi Benda Cagar Budaya (BCB) dan Kepurbakalaan. Serang: Dinas Budpar Provinsi Banten.

Instruksi Menteri No. 22 Tahun 1999 tentang Petunjuk Pelaksanaan UU Nomor 15 Tahun 1999 tentang Pembentukan Kotamadya DT. II Depok dan Kotamadya DT. II Cilegon.

Madomiharna, et.al. 1957.

Menudju Otonomi Seluas-luasnja., DPRD Kab. DT II Bandung.

Menteri Dalam Negeri RI, Sambutan Menteri Dalam Negeri RI pada Rapat Paripurna DPR-RI dalam Rangka Pembicaraan Tingkat IV Pengambilan Keputusan atas 8 (delapan) RUU tentang Pembentukan 11 (Sebelas) Daerah
Tingkat II, yaitu Kotamadya DT. II Cilegon, Cilegon, Dumei, Ternate, Banjar Baru, Metro dan Kabupaten DT. II Aceh Singkil, Luwu Utara, Bengkayang, Lampung Timur, dan Way Kanan tanggal 29 Maret 1999.

Pemkot Kota Cilegon. 2007.

9 Tahun Membangun Kota Cilegon, Tiada Hari Tanpa Perbaikan dan Kebaikan.

Pemkot Kota Cilegon. 2007.

Sewindu Kota Cilegon, Membangun Bersama dan Berkarya. Cilegon.

Perda Kabupaten Kota Cilegon No. 15 Tahun 2001 Tentang Rencana Tata Ruang Kota Administratif Cilegon sampai Tahun 2000-2010.

Perda Kota Cilegon No. 46 Tahun 2001 tentang Kewenangan.

Perda Kota Cilegon No. 47 Tahun 2001 tentang Perangkat Daerah.

Perda Kota Cilegon No. 48 tentang Susunan Organisasi Perangkat Daerah. 